\title{
PRELIMINARY ADVICE ON FRUIT HANDLING, SEED PRETREATMENT AND 'GERMINATION' OF EMBRYOS OF PRUMNOPITYS ANDINA
}

\author{
Peter G. Gosling ${ }^{1}$, Lorelie M. Ives ${ }^{1}$, Victoria J. Cunningham ${ }^{1}$, Paulina Hechenleitner $V^{2}$, \\ Peter Brownless ${ }^{3}$, Philip Thomas \& Camila Martinez ${ }^{3}$
}

Prumnopitys andina is a member of the Podocarpaceae native to Chile and Argentina. It is known to be relatively easy to propagate vegetatively, but germination from seeds is poor and can be spread over at least four years. This paper describes the methods that were used to raise 89 seedlings from 262 seeds $(=34 \%)$ in less than 1 year. The sequence involves i) completely removing the fleshy sarcotesta; ii) thoroughly washing the seed-coat; iii) 'pretreating' the imbibed seeds by incubating them in moist peat and sand at a daily alternating $10 / 15^{\circ} \mathrm{C}$ for several months (to allow 'maturation' or 'after-ripening'/'dormancy breakage' at present we do not know which); iv) carefully cracking the seed-coat in a vice and extracting the embryo; v) culturing clean, firm, healthy (='viable') embryos on moist filter paper at a daily alternating $20 / 30^{\circ} \mathrm{C}$ (with lights during the $30^{\circ} \mathrm{C}$ phase); [vi) where necessary, freeing the cotyledons of all seedlings that become trapped in the female gametophyte]; vii) transplanting seedlings to conventional nursery practice. A further 1008 seeds are continuing 'pretreatment' to investigate whether this will increase the proportion of seedlings per viable embryo or better still lead to a much less labour intensive seedling emergence from intact seeds.

\section{INTRODUCTION}

Prumnopitys andina (Poepell. ex Endl.) de Laub. is an evergreen member of the Podocarpaceae native to Chile and Argentina. In Chile, it is distributed between $35^{\circ} 50^{\prime}$ to $39^{\circ} 30^{\prime}$ S along the Andes (Rodríguez \& Quezada, 1995). It crosses the Andes into Argentina at about $38^{\circ} \mathrm{S}$ (Tortorelli, 1956). There is a little known population in the Cordillera de Nahuelbuta close to Angol (37 $50^{\circ} \mathrm{S} 72^{\circ} 50^{\prime} \mathrm{W}$ ) which is rapidly dwindling in size due to land conversion to commercial forestry (Gardner and Lara, 2003). In other parts of its range, populations have been reduced by overgrazing, selective felling and hydroelectric developments. Its conservation status has recently been assessed according to IUCN 2001 categories as Vulnerable [B2a, b(ii-v)] (Hechenleitner et al, 2005).

The germination of podocarps (in general) is very slow and unreliable (Laughton, 1938; Palmer and Pitman, 1972). It has been noted that the germination of some may be hastened by completely or partially removing the fleshy epimatium (Phillips, 1931; Becking, 1965; Noel and van Staden, 1976) and others by 'cautiously cracking the nut'

\footnotetext{
'Peter G. Gosling is the Project Leader, 'Lorelie M. Ives is the Assistant Project Support Officer, 'Victoria J. Cunningham is the Project Support Officer, Address: Forest Management Division, Forestry Commission Research Agency, Alice Holt Lodge, Wrecclesham, Farnham, Surrey, GU10 4LH. Email:peter.gosling@forestry.gsi.gov.uk lorelie.ives@forestry.gsi.gov.uk victoria.cunningham@forestry.gsi.gov.uk

${ }^{2}$ Paulina Hechenleitner-V is the Curator of UACh Arboretum Instituto de Silvicultura, Facultad de Cs. Forestales, Universidad Austral de Chile, Valdivia, Casilla 567, Chile Email:phechenleitner@uach.cl

${ }^{3}$ Peter Brownless is a Garden Supervisor, ${ }^{3} \mathrm{Philip}$ Thomas is a Research Officer \& ${ }^{3}$ Camila Martinez is a Research Student at the RBGE. Royal Botanic Garden Edinburgh, 20a Inverleith Row, Edinburgh, EH3 5LR Email:p.brownless@rbge.org.uk p.thomas@rbge.org.uk, Email:camilasp@surnet.cl
} 
(Sim, 1905). Looby and Doyle (1944) have speculated that embryo immaturity at fruitfall may be 'a common podocarpean feature', and that a period of what they have termed 'after-development' may be important. Clout and Tilley (1992) reported that seeds of Prumnopitys ferruginea continued to germinate for over four years - either with, or without passage through a pigeon gut. And Gardner and Lara (2003) also indicate that propagation trials on Prumnopitys andina at the Royal Botanic Garden Edinburgh (RBGE) resulted in poor germination, spread over up to four years. Rodríguez (1988) and Rodríguez (2004) observed that chemical and mechanical scarification of the seeds of this species could shorten the germination period.

This paper reports the preliminary findings from a joint study between the British Forestry Commission, Forest Research Agency, Royal Botanic Garden Edinburgh and the Instituto de Silvicultura, Universidad Austral de Chile, Valdivia. The main aim of the study was to obtain as many seedlings as possible from a total of 1270 fruits obtained from 12 different seed accessions. At the same time we attempted to significantly shorten the propagation period.

\section{TERMINOLOGY}

Mill et al. (2004) have recently published descriptions of the anatomy and morphology of fertile complexes of Prumnopitys and Afrocarpus species. In this paper we have followed their terminology and also used some practical descriptions of the tissues. This section attempts to clarify our terminology. The fully ripened 'female cones' were approximately $20 \mathrm{~mm}$ long and $15 \mathrm{~mm}$ wide, fleshy and olive-green in colour (Plate 1). For brevity they

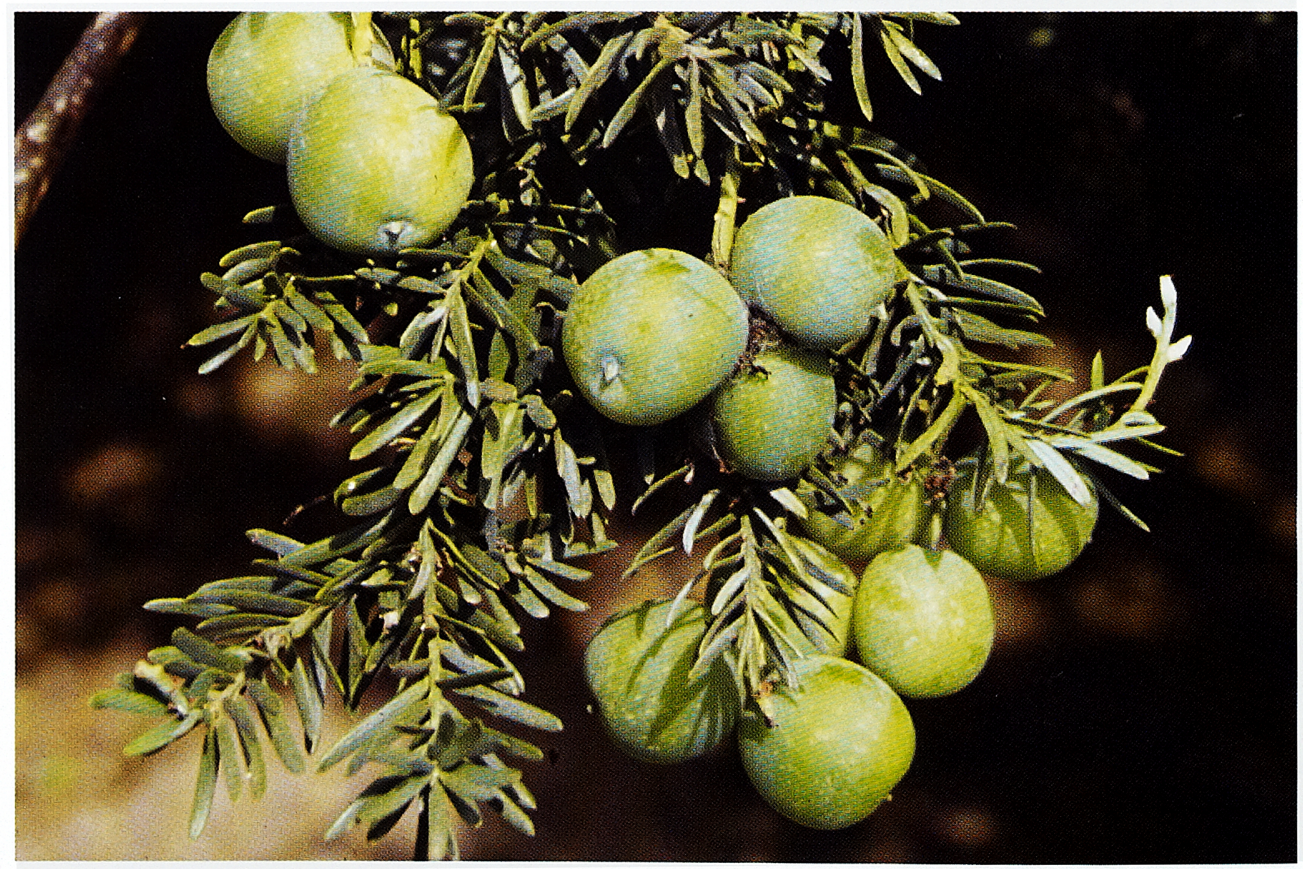

Plate 1. Foliage and fruit of Prumnopitys andina 
are loosely referred to as 'fruits'. The olive green, fleshy tissue itself is referred to as 'sarcotesta' (Mill et al., 2004) - believed to be fused integument plus epimatium (c.f. epimatium only, of other podocarp fruits). Removal of this tissue (in a process we call de-pulping) revealed the equivalent of a cherry 'stone'. This is the 'seed' (Plates 2a-c). Cracking and removing the hard 'seed-coat' allowed an 'embryo' to be extracted (Plate $2 \mathrm{~d}$ ). The outermost tissues of the embryo are the 'female gametophyte' which enclosed an extremely tiny (sometimes invisible to the naked-eye) 'embryonic axis'.

\section{COLLECTION}

1270 ripe fruits (olive green in colour) were collected (usually from the branches of trees) from 12 different locations in Chile in January and February 2004 (Table 1). The numbers of fruits from each tree plus their collection and accession codes are recorded in Table 2, column 1 . The fruits from each accession were kept separately for all subsequent treatments.

Table 1. Accession numbers and collection information.

\begin{tabular}{|c|c|c|c|c|c|c|c|c|}
\hline 20040044 & $\mathrm{DCI}^{*} 708$ & 16-Jan-04 & $\begin{array}{l}\text { Región VIII } \\
\text { [Biobío] }\end{array}$ & $\begin{array}{l}\text { Provincia de } \\
\text { Biobío }\end{array}$ & Santa Bárbara & 963 & $37^{\circ} 43^{\prime} 21.7^{\prime \prime}$ & $71^{\circ} 14^{\prime} 48^{\prime \prime}$ \\
\hline 20040045 & $\mathrm{DCI} * 717$ & 16-Jan-04 & $\begin{array}{l}\text { Región VIII } \\
\text { [Biobío] }\end{array}$ & $\begin{array}{l}\text { Provincia de } \\
\text { Biobío }\end{array}$ & Santa Bárbaira & 852 & $37^{\circ} 41^{\prime} 35.1^{\prime \prime}$ & $71^{\circ} 18^{\prime} 23.6^{\prime \prime}$ \\
\hline 20040053 & DCI*725 & $16-J a n-04$ & $\begin{array}{l}\text { Región VIII } \\
\text { [Biobío] }\end{array}$ & $\begin{array}{l}\text { Provincia de } \\
\text { Biobío }\end{array}$ & Santa Bárbara & 777 & $37^{\circ} 43^{\prime} 07.3^{\prime \prime}$ & $71^{\circ} 21^{\prime} 39^{\prime \prime}$ \\
\hline 20040082 & DCI*923 $^{*}$ & 25-Jan-04 & $\begin{array}{l}\text { Región IX } \\
\text { [Araucanía] }\end{array}$ & $\begin{array}{l}\text { Provincia de } \\
\text { Malleco }\end{array}$ & Cautín & 1,023 & $38^{\circ} 41^{\prime} 09.7^{\prime \prime}$ & $71^{\circ} 37^{\prime} 14.8^{\prime \prime}$ \\
\hline 20040097 & DCI*1009 & 28-Jan-04 & $\begin{array}{l}\text { Región VIII } \\
\text { [Biobío] }\end{array}$ & $\begin{array}{l}\text { Provincia de } \\
\text { Biobío }\end{array}$ & Antuco & 868 & $37^{\circ} 11^{\prime} 19.3^{\prime \prime}$ & $71^{\circ} 26^{\prime} 28.3^{\prime \prime}$ \\
\hline 20040098 & $\mathrm{DCl}^{*} 1015$ & 28-Jan-04 & $\begin{array}{l}\text { Región VIII } \\
\text { [Biobío] }\end{array}$ & $\begin{array}{l}\text { Provincia de } \\
\text { Biobío }\end{array}$ & Antuco & 868 & $37^{\circ} 12^{\prime} 03.6^{\prime \prime}$ & $71^{\circ} 26^{\prime} 54^{\prime \prime}$ \\
\hline 20040099 & DCI*1027 & 28-Jan-04 & $\begin{array}{l}\text { Región VIII } \\
\text { [Biobío] }\end{array}$ & $\begin{array}{l}\text { Provincia de } \\
\text { Biobío }\end{array}$ & Antuco & 859 & $37^{\circ} 13^{\prime} 52.6^{\prime \prime}$ & $71^{\circ} 26^{\prime} 40.9^{\prime \prime}$ \\
\hline 20040100 & DCI*1036 & 28-Jan-04 & $\begin{array}{l}\text { Región VIII } \\
\text { [Biobío] }\end{array}$ & $\begin{array}{l}\text { Provincia de } \\
\text { Biobío }\end{array}$ & Antuco & 797 & $37^{\circ} 15^{\prime} 38.2^{\prime \prime}$ & $71^{\circ} 27^{\prime} 23.6^{\prime \prime}$ \\
\hline 20040113 & DCI*1093 & 30-Jan-04 & $\begin{array}{l}\text { Región VIII } \\
\text { [Biobío] }\end{array}$ & $\begin{array}{l}\text { Provincia de } \\
\text { Ñuble }\end{array}$ & Pinto & 787 & $36^{\circ} 51^{\prime} 03.0^{\prime \prime}$ & $71^{\circ} 38^{\prime} 46.6^{\prime \prime}$ \\
\hline 20040139 & DCI*1141 & 01-Feb-04 & $\begin{array}{l}\text { Región VII } \\
\text { [Maule] }\end{array}$ & $\begin{array}{l}\text { Provincia de } \\
\text { Linares }\end{array}$ & Colbún & 906 & $35^{\circ} 53^{\prime} 27.7^{\prime \prime}$ & $70^{\circ} 59^{\prime} 32.6^{\prime \prime}$ \\
\hline 20040140 & DCI*1142 & $01-F e b-04$ & $\begin{array}{l}\text { Región VII } \\
\text { [Maule] }\end{array}$ & $\begin{array}{l}\text { Provincia de } \\
\text { Linares }\end{array}$ & Colbún & 913 & $35^{\circ} 53^{\prime} 23.8^{\prime \prime}$ & $70^{\circ} 59^{\prime} 29.5^{\prime \prime}$ \\
\hline 20040141 & DCI*1155 & 01-Feb-04 & $\begin{array}{l}\text { Región VII } \\
\text { [Maule] }\end{array}$ & $\begin{array}{l}\text { Provincia de } \\
\text { Linares }\end{array}$ & Colbún & 1,000 & $35^{\circ} 53^{\prime} 03.7^{\prime \prime}$ & $70^{\circ} 59^{\prime} 19.3^{\prime \prime}$ \\
\hline
\end{tabular}




\section{TEMPORARY STORAGE AND TRANSPORT OF FLESHY FRUITS}

Fruits were kept at $4^{\circ} \mathrm{C}$ or occasionally $15^{\circ} \mathrm{C}$ in loosely tied polythene bags. During transport they were thermally insulated. Some accessions were stored for up to 4 months at $4^{\circ} \mathrm{C}$ and this led to the green flesh of some fruits darkening through brown to black with the release of a viscous, sticky fluid - probably a resin.

\section{FRUIT DE-PULPING AND SEED EXTRACTION}

The ripe, fleshy, olive-green (or sometimes blackening) fruits were placed in a metal sieve. Flesh was carefully removed by squeezing the sticky fruits between the fingers and against the sieve sometimes using sand as a cleaning agent. Care was taken to remove all traces of flesh from the hard, seed coat. De-pulped seeds were immediately transferred to a beaker, the top of the beaker covered with gauze (to prevent subsequent loss of seeds). Seeds were then washed and agitated in running water at about $15^{\circ} \mathrm{C}$ for 12 hours - as a means of removing any potential chemical germination inhibitors that might be present. A random sample of 20 seeds was taken from Accession nos. 20040097 and 20040099 (because they contained the most seeds) and used to a) develop a suitable 'seed cracking and embryo extraction' technique (see below) and b) develop a method for 'viable' seed assessment (see below).

\section{SEED CRACKING, EMBRYO EXTRACTION AND 'VIABLE' SEED ASSESSMENT}

Preliminary trials using a nut-cracker and a hammer on the hard-coated seeds either bruised, partially squashed or completely flattened the contents of the seeds! We therefore refined a technique which is frequently used in so-called 'excised embryo' testing, employing a suitably sized vice as an ideal seed cracking tool (Plate 3 ). This method has also been successfully applied to raise seedlings of Prumnopitys ferrüginea (Parratt, pers comm). One seed at a time was inserted into the vice, taking care to hold the longest axis of the seed vertically and the widest profile of the seed across the jaws (Plates $2 \mathrm{a} \& 3$ ). The jaws of the vice were tightened slowly to crack the seed coat and cause as little damage as possible to the contents. The seed case was then carefully prised away from the contents using fingernails and/or a dissecting instrument such as a diamond headed probe. Observations on the seed contents coupled with the principles of a seed viability assessment described by Gosling (2003) were used to categorise seeds as follows:

1. Seeds with less than $50 \%$ contents - 'empty'.

2. Seeds containing obviously discoloured, dying, rotting or dead tissues - 'dead'.

3. Seeds with clean, firm, fresh, healthy, apparently live tissues - 'viable' (Plate 2d). Only 'viable' embryos from this technique were 'cultured' (see below). 


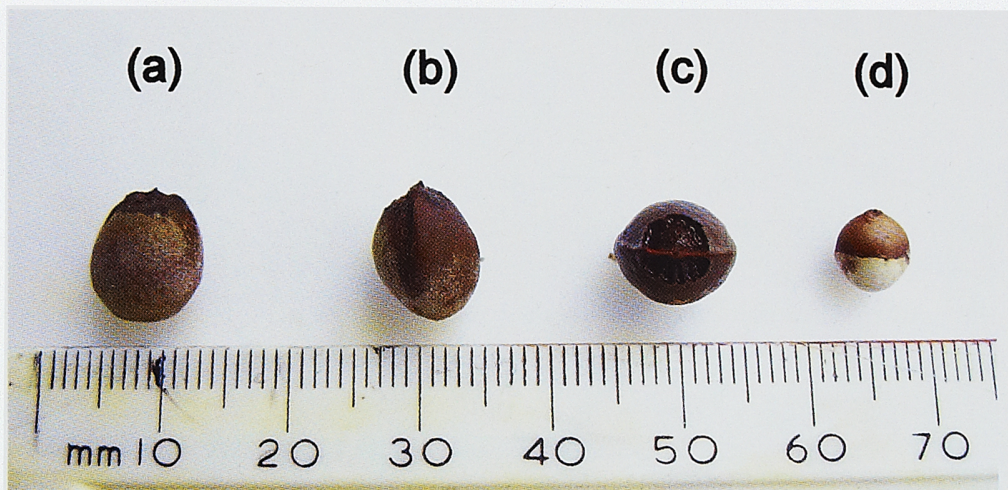

Plate 2. Seeds of Prumnopitys andina. (a) - (c) Different orientations, (d) Extracted embryo.

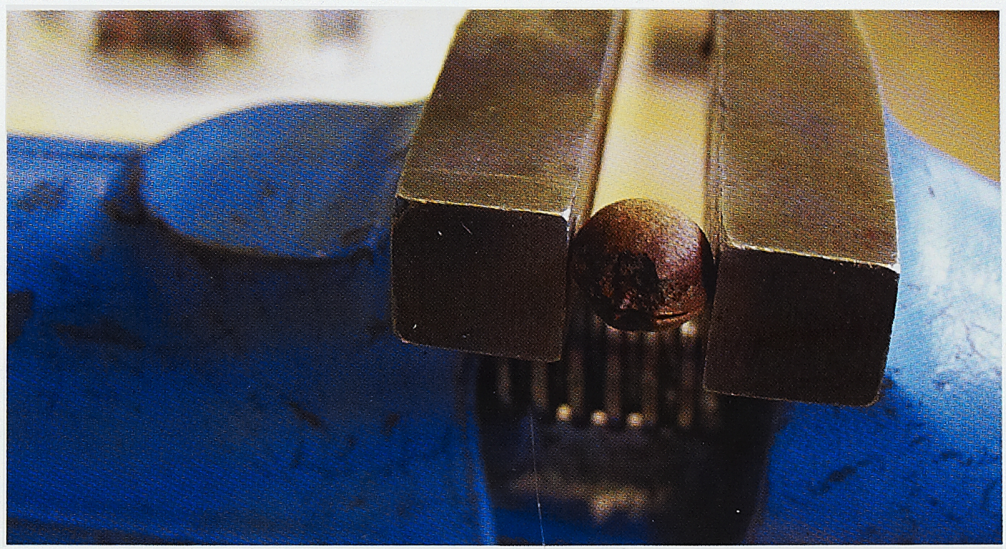

Plate 3. Cracking the hard seed coat of $P$. andina in a suitably sized vice. (Note the orientation of the seed)

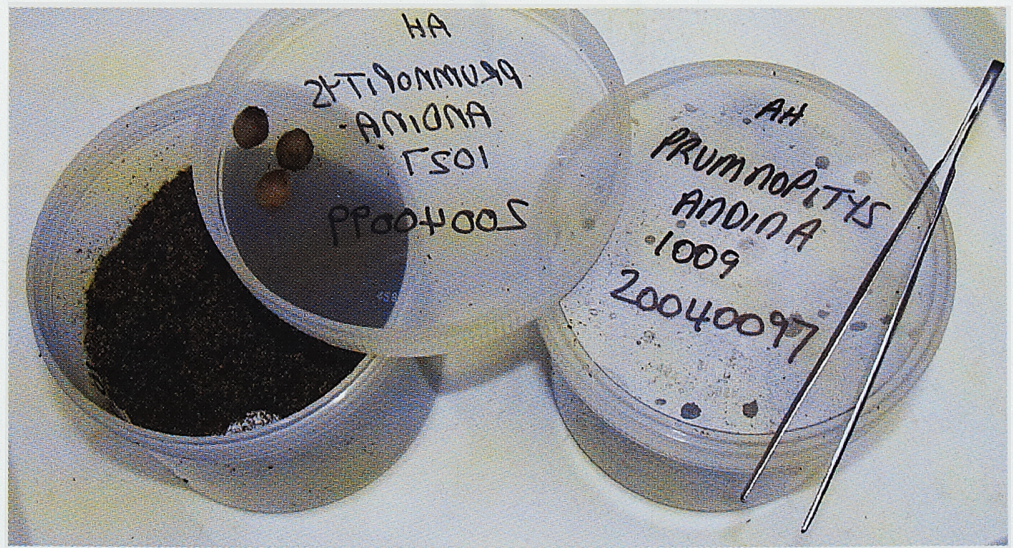

Plate 4. Pretreatment of seeds in moist peat and sand in containers which allow gaseous exchange. 


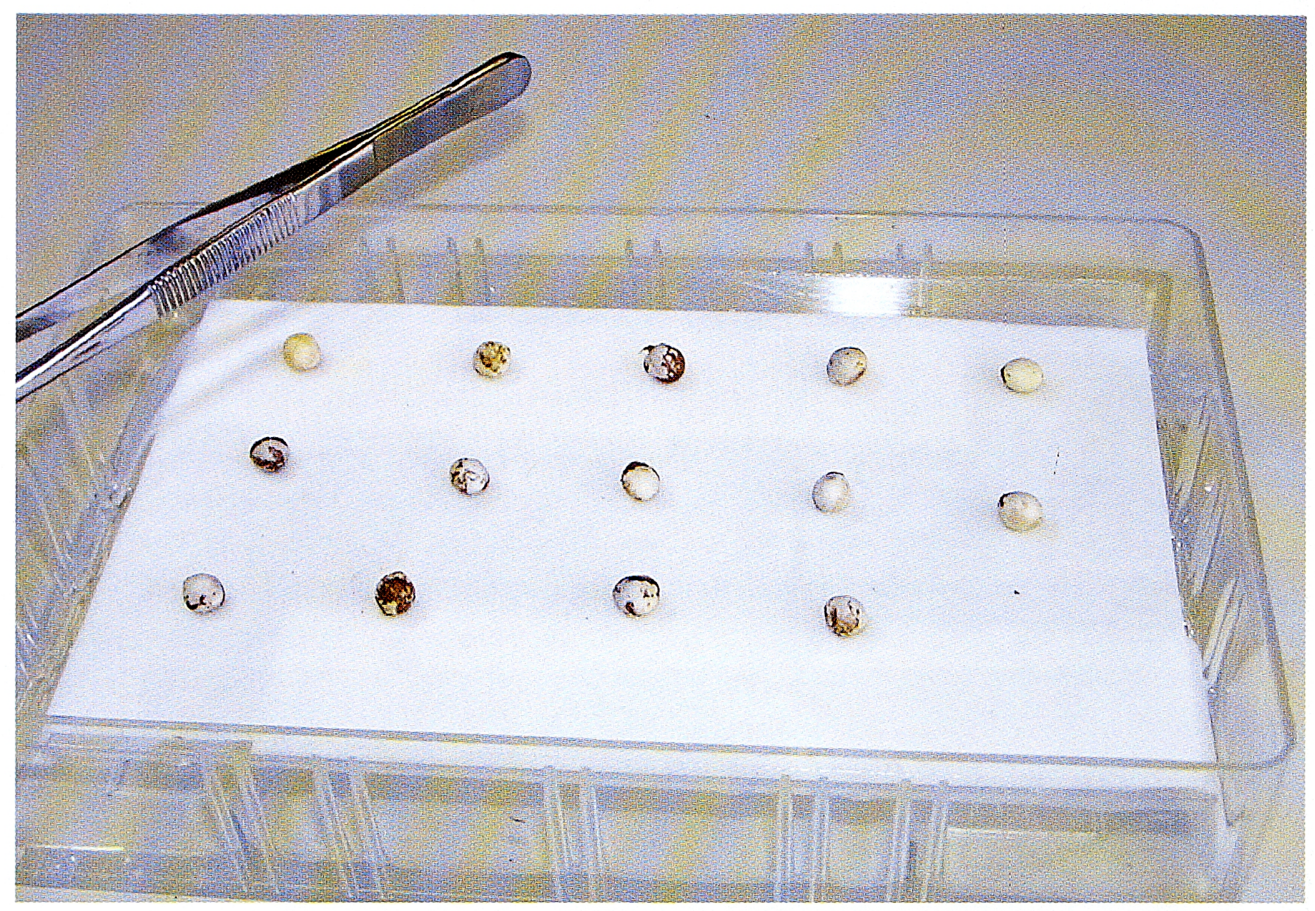

Plate 5. Embryo culture on moist filter paper. Water rises from the reservoir below. Lid is not shown.

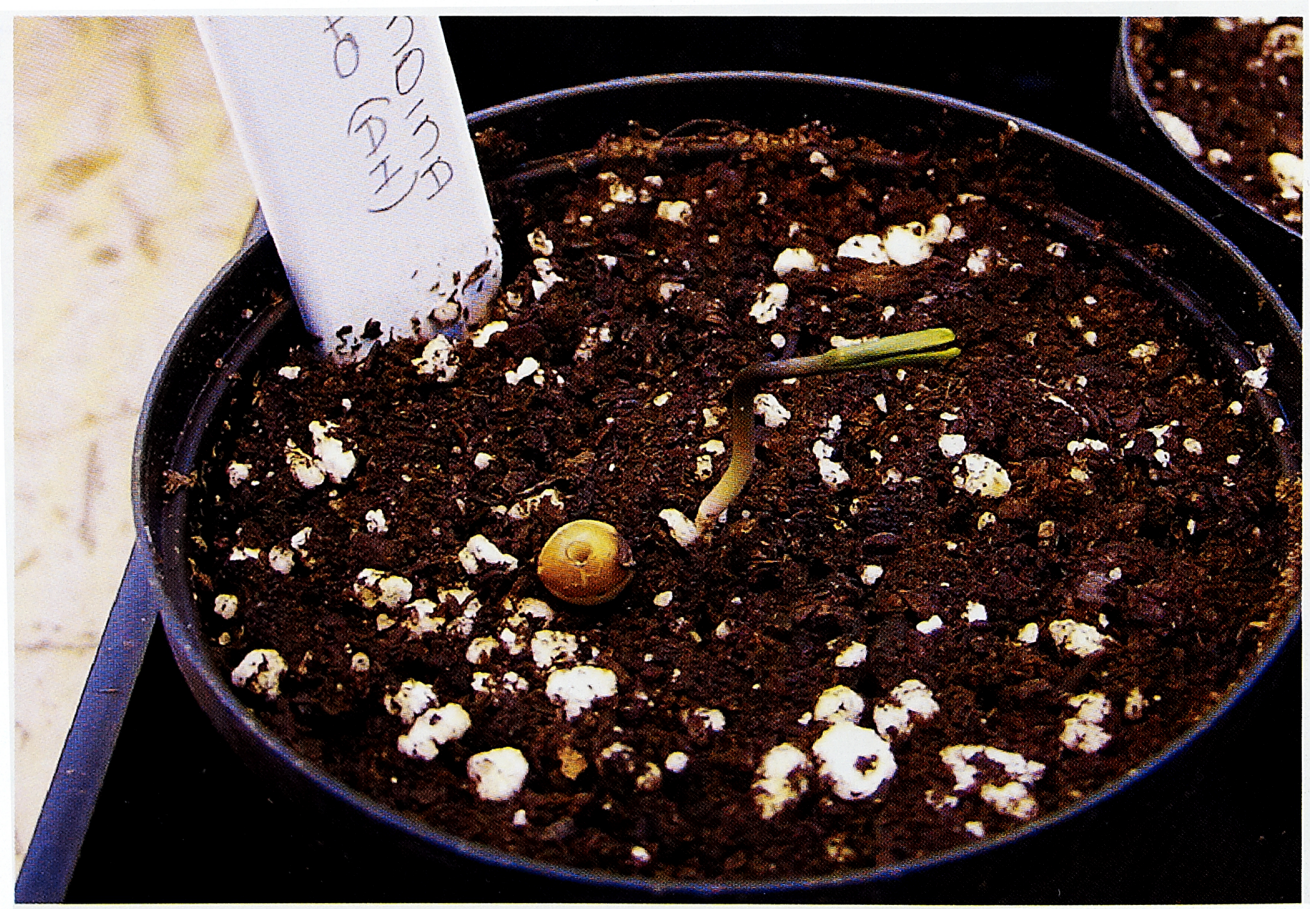

Plate 6. Prumnopitys andina seedling in a three inch pot. The female gametophyte is to the left of the seedling. The aperture visible indicates where the cotyledons were inserted. 


\section{SEED PRETREATMENT}

On 18 August 2004, washed, fully imbibed seeds were mixed with 4 volumes of moist peat and sand (1:1 volume to volume ratio) and incubated in the dark at a daily alternating $10-15^{\circ} \mathrm{C}(12 \mathrm{~h}: 12 \mathrm{~h})$ in a container that minimised moisture loss, but allowed some gaseous exchange (Plate 4). At weekly intervals, the containers were opened (which allowed extra gaseous exchange), and the pretreating seeds inspected. If necessary the medium was sprayed with Reverse Osmosis (R.O.) water (to ensure that the medium remained sufficiently moist) and obviously decaying or dead seeds were removed (to prevent fungal infections from developing or spreading). Any seeds that germinated were 'potted-on' (see below). After 5 and 7 months a small, random sample of seeds was taken from each accession, the seeds cracked, and embryos cultured where possible (Table 1, columns $4 \& 5$ ). It is intended to continue this process at 12, 15, 18, 21 and 24 months.

\section{EMBRYO CULTURE}

Embryos were transferred to moist filter paper and incubated at a daily alternating $20-30^{\circ} \mathrm{C}\left(16 \mathrm{~h}\right.$ at $20^{\circ} \mathrm{C}$ in the dark $/ 8 \mathrm{~h}$ at $30^{\circ} \mathrm{C}$ in light) (Plate 5). At daily intervals, they were inspected for signs of growth. A protruding root was generally the first sign of seedling emergence. Some emerged within a few days, others took much longer. Most seedlings emerged with 2 cotyledons though some had 3. It is very important to note that the cotyledons of many of these 'forced' seedlings become trapped in the female gametophyte. Whenever this happened, it was essential to very carefully tease the female gametophyte from the seedling. Sometimes this had to be attempted daily over the course of up to a week, but failure to remove the female gametophyte after a couple of weeks could lead to seedling death. Quiescent embryos were only discarded if they succumbed to mould.

\section{POTTING-ON SEEDLINGS}

Seedlings that germinated 'naturally' during pretreatment, or those derived from embryo culture were both transplanted into $75 \mathrm{~mm}$ pots containing peat:perlite:bark (1:1:1 volume: volume:volume ratio). For about two weeks the pots plus seedlings were incubated at a daily alternating $20-30^{\circ} \mathrm{C}$ and were then transferred to a heated poly-tunnel (Plate 6). Irrigation and fertiliser application were carried out according to conventional nursery practice. It is very important to note that, in common with the embryo culture technique, the cotyledons of many of the naturally germinated seedlings also became trapped in the female gametophyte. However, naturally germinated seedlings could not be freed from the combined female gametophyte plus hard seed coat, and all died. 


\section{RESULTS AND DISCUSSION}

The main aim of this study was to obtain as many seedlings as possible from the 1270 fruits from the 12 different seed accessions. A secondary aim was to propagate these seedlings in less time than the 4 years currently reported by Clout and Tilley (1992) for Prumnopitys ferruginea and Gardner and Lara (2003) for P.andina.

It became clear at the earliest stages of the investigation that to achieve either of the above aims required the equivalent of a 'quality assurance' check on the proportion of seeds that were likely to contain embryos with the potential to germinate. Initially, we tried to $\mathrm{x}$-ray the freshly de-pulped, intact seeds, but because the seeds were fully imbibed, the high moisture content rendered them x-ray opaque. Since we did not wish to dry the seeds, we employed a method for cracking them in a suitably sized vice and extracting the embryos without causing physical damage (Plate 3). Just over half the seeds (Table 2, bottom of column 5) contained fresh, healthy, apparently live embryos, but because some contained obviously shrivelled, dead or dying contents and others, nothing at all, we adopted the 'viable' seed assessment of Gosling (2003). This proved very useful for two reasons. First, further dissection of a few the embryos of the 'viable' seeds confirmed the speculations of Looby and Doyle (1994) - that embryo immaturity was a feature of $P$. andina. Second, this observation suggested that if the seeds could be incubated under favourable conditions for growth, then embryo maturation or even after-ripening might take place - leading to better developed, 'viable' embryos suitable for culturing into seedlings. These proved to be the bases for the successful procedures described and illustrated above.

Table 2 shows that although we have only worked on $21 \%$ of the 1270 fruits, most accessions have just over $50 \%$ of 'viable' seeds and after about 6 months 'pretreatment' almost $66 \%$ of viable seeds are capable of producing a seedling. This equates to an overall $34 \%$ of seeds used producing a seedling, in less than 1 year since collection.

Clearly, these are already very effective methods of collection, transport, handling, processing and pretreatment - although it is acknowledged that the seed cracking and embryo extraction technique is extremely time consuming and labour intensive.

We have not applied the technique to all of the remaining seeds for two reasons. First, we do not wish to raise all this valuable material to the sensitive 'seedling' stage. Second, because we hope to extend the pretreatment period and observe whether this either increases the proportion of seedlings further or better still leads to much less labour intensive seedling emergence from intact seeds.

It is intended to use the methodology in Chile where it will not only contribute towards conservation but will also play a small part in local poverty alleviation. 
Table 2. Numbers and percentages of fruits, seeds, viable seeds and seedlings obtained from each accession of Prumnopitys andina at the different stages of handling. (Percentages are based on the number of fruits, seeds, viable seeds at the preceding stage.)

Fruits were collected in February-March 2004 and stored at $4^{\circ} \mathrm{C}$; fruits de-pulped April July 2004 and extracted seeds mixed with moist peat and sand and returned to $4^{\circ} \mathrm{C}$; seed pretreatment in moist peat and sand at $10-15^{\circ} \mathrm{C}$ began on 18 August 2004.

\begin{tabular}{|c|c|c|c|c|c|}
\hline \multirow[t]{2}{*}{20040044} & 122 & 4 Aug 04 / 1 & & & 0 \\
\hline & & & 8 Mar 05 / 24 & $1(4 \%)$ & 0 \\
\hline \multirow[t]{3}{*}{20040045} & 110 & $18 \mathrm{Jan} 05 / 1$ & & & 0 \\
\hline & & & $26 \operatorname{Jan} 05 / 18$ & $10(56 \%)$ & $5(50 \%)$ \\
\hline & & & $8 \operatorname{Mar} 05 / 21$ & $9(43 \%)$ & $4(44 \%)$ \\
\hline 20040053 & 122 & & 8 Mar $05 / 24$ & $3(13 \%)$ & $2(66 \%)$ \\
\hline *20040082 & 49 & & $8 \operatorname{Mar} 05 / 10$ & 0 & 0 \\
\hline \multirow[t]{2}{*}{20040097} & 172 & & $26 \operatorname{Jan} 05 / 6$ & $5(83 \%)$ & $5(100 \%)$ \\
\hline & & & $8 \operatorname{Mar} 05 / 27$ & $18(67 \%)$ & $9(50 \%)$ \\
\hline 20040098 & 110 & & $8 \operatorname{Mar} 05 / 21$ & $17(81 \%)$ & $12(71 \%)$ \\
\hline 20040099 & 173 & & 8 Mar 05 / 34 & $13(38 \%)$ & $11(85 \%)$ \\
\hline \multirow[t]{3}{*}{20040100} & 100 & $15 \mathrm{Dec} 04 / 2$ & & & 0 \\
\hline & & 17 Jan $05 / 1$ & & & 0 \\
\hline & & & $8 \operatorname{Mar} 05 / 15$ & $13(81 \%)$ & $5(38 \%)$ \\
\hline 20040113 & 99 & & 8 Mar $05 / 19$ & $17(89 \%)$ & $14(82 \%)$ \\
\hline 20040139 & 72 & & $8 \mathrm{Mar} 05 / 14$ & $10(71 \%)$ & $8(80 \%)$ \\
\hline 20040140 & 85 & & $8 \operatorname{Mar} 05 / 17$ & $14(82 \%)$ & $10(71 \%)$ \\
\hline 20040141 & 56 & & 8 Mar $05 / 11$ & $5(46 \%)$ & $4(80 \%)$ \\
\hline TOTALS & 1270 & 4 & $262(21 \%)$ & $135(52 \%)$ & $89(66 \%)$ \\
\hline
\end{tabular}

*Accession number 20040082 was collected from the ground and probably consisted of the previous year's fruits. This may explain the absence of any viable seeds. 


\section{ACKNOWLEDGEMENTS}

Many thanks to Richard Jinks, Robert Mill, Martin Gardner and Matt Parratt for their many useful contributions to our discussions on methodology and their helpful suggestions for revising the text. Thanks also to Steve Coventry for his help in raising the seedlings. The Royal Botanic Garden Edinburgh is supported by the Scottish Executive Environment and Rural Affairs Department (SEERAD). The field-work in Chile was supported by a Darwin Initiative Grant (162/10/012) 'An integrated conservation programme for threatened endemic forest species in Chile'.

\section{REFERENCES}

BECKING, J.H. (1965). Nitrogen fixation and mycorrhiza in Podocarpus root nodules. Plant \& Soil, 23: 213-226

CLOUT, M.N. \& TILLEY, J.A.V. (1992). Germination of miro (Prumnopitys ferruginea) seeds after consumption by New Zealand pigeons (Hemiphaga novaeseelandiae). New Zealand J. Bot. 30: 25-28

GARDNER, M.F. \& LARA, A. (2003) The conifers of Chile: an overview of their distribution and ecology. Proc. of the Fourth International Conifer Conference (Wye College, UK, 1999). Ed. R.R. Mill. Acta Horticulturae 615: 165-170.

GOSLING, P.G. (2003) Seed viability testing, pp 445-481. In: Seed Conservation: Turning science into practice. SMITH, R.D., DICKIE, J.B., LININGTON, S.H., PRITCHARD, H.W. \& PROBERT, R.J. Eds. Publ. Royal Botanic Gardens, Kew.

HECHENLEITNER, P., GARDNER, M., THOMAS, P., ECHEVERRIA, C., ESCOBAR, B., BROWNLESS, P. \& MARTINEZ, C. (2005) Plantas amenazadas centro-sur de Chile, distribucion, conservacion y propagacion. Valdivia: UACh, Edinburgh: RBGE.

LAUGHTON, F.S. (1938). The raising of transplants of indigenous tree species for open-rooted planting. J.S.A. Forestry Association, 1. 17-27.

LOOBY, W.J. \& DOYLE, J. (1944). Fertilisation and early embryogeny in Podocarpus. Sci Proc Royal Dublin Soc 23: 257-270

MILL, R. R., MÖLLER, M., GLIDEWELL, S. M., MASSON, D. \& WILLIAMSON, B. (2004). Comparative anatomy and morphology of fertile complexes of Prumnopitys and Afrocarpus species (Podocarpaceae) as revealed by histology and NMR imaging, and their relevance to systematics. Bot. J. Linn Soc 145: 295-316.

NOEL, A.R.A \& VAN STADEN, J. (1976). Seed coat structure and germination in Podocarpus henkelii. Z. Pflanzenphysiol. Bd. 77: 174-186.

PALMER, E. \& PITMAN, N. (1972). Trees of Southern Africa 1. Cape Town, S. Africa.Balkema.

PHILLIPS, J.F.V. (1931). Forest Succession and Ecology in the Knysna Region. Bot. Surv. S.A. Mem. 14, Pretoria. Govt. Printer.

SIM, T.R. (1905). Tree Planting in Natal. Pietermaritzburg.P. Davis.

RODRÍGUEZ, R. (1988). Lleuque. Prumnopitys andina (Poepp ex Endl.) de Laub. Ficha Coleccionable. Chile Forest. 148: 33-34.

RODRÍGUEZ, R. (2004). Monografía Lleuque (Prumnopitys andina) Especie con Problemas de Conservación en Chile. Concepcion: ENDESA 47 pp.

RODRÍGUEZ, R. \& M. QUEZADA. (1995). Gymnospermae: 321-322. En: MARTICORENA, C. \& R. RODRÍGUEZ (eds.). Flora de Chile. Vol. 1. Pteridophyta-Gymnospermae.

Concepcion: Universidad de Concepción, Chile. $351 \mathrm{pp}$.

TORTORELLI, L.A. (1956). Maderas y Bosques en la Argentina. Buenos Aires: Editorial Acme. 